\title{
Oracula Mortis in the Pharsalia
}

John F. Makowski

Loyola University Chicago, jmakow1@luc.edu

Follow this and additional works at: https://ecommons.luc.edu/classicalstudies_facpubs

Part of the Ancient History, Greek and Roman through Late Antiquity Commons, and the Classical Literature and Philology Commons

\section{Recommended Citation}

Makowski, JF. "Oracula Mortis in the Pharsalia" in Classical Philology 72(3), 1977. 193-202.

This Article is brought to you for free and open access by the Faculty Publications and Other Works by Department at Loyola eCommons. It has been accepted for inclusion in Classical Studies: Faculty Publications and Other Works by an authorized administrator of Loyola eCommons. For more information, please contact ecommons@luc.edu. (c) (i) $\left(\mathrm{O}_{\mathrm{EY}}\right.$

This work is licensed under a Creative Commons Attribution-Noncommercial-No Derivative Works 3.0 License. (c) University of Chicago Press, 1997. 


\title{
ORACULA MORTIS IN THE PHARSALIA
}

\author{
JOHN F. MAKOWSKI
}

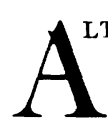

LTHOUGH it departs from epic convention in many ways, most notably in the rejection of the deorum ministeria, the Pharsalia adheres to tradition in the matter of oracles and contains three visitations to a seat of prophecy. Appius goes to Delphi (5. 67-236), Sextus Pompeius to the Thessalian witch Erichtho (6. 413-830), and Cato to the temple of Jupiter Hammon (9. 511-86). The obvious similarities of the situations invite comparison, but no one has as yet attempted to analyze them as a unit. ${ }^{1}$ Such a study, however, will be fruitful because the three episodes have more in common than first meets the eye. For they all develop a number of themes which are central to the epic, and taken together, they constitute a tripartite statement on the place of foreknowledge, on man's relationship to the gods, and on the meaning of death. Furthermore, they are instructive for understanding Lucan's technique in using and portraying minor characters.

In each episode three considerations are important. First, there is the character of the consulter, both from what we know of him as a historical personage and from what Lucan himself tells us. Second, there is the oracle's credibility and efficacy, as evaluated from the poet's description and from the response given the consulter. And third, it is important to notice in each scene any references, direct or indirect, to one or both of the other oracles.

The first to seek knowledge of the future is the Pompeian Appius Claudius Pulcher, a former augur and author on divination. ${ }^{2}$ And what kind of man is he? Lucan gives a clue in the lines which introduce him (5. 67-70):

solus in ancipites metuit descendere Martis Appius eventus, finemque expromere rerum sollicitat superos multosque obducta per annos Delphica fatidici reserat penetralia Phoebi.

The key word here is metuit. Appius' motive in consulting Delphi is fear. ${ }^{3}$ A coward at heart, he dreads the uncertainty of war and troubles the gods to find out how the conflict will end. Later, toward the close of the scene,

1. Critics have treated the scenes singly or in $\mathrm{p}_{\mathrm{i}} \rightarrow$ B. F. Dick has written two studies on oracular and prophetic elements in Lucan: "The Role of the Oracle in Lucan's De Bello Civili," Hermes 93 (1965): 460-66; and "The Technique of Prophecy in Lucan," TAPA 94 (1963): 31-49. In the first Dick treats the Appius and Cato scenes; in the second he discusses the Erichtho passage within the context of magic in the Pharsalia. The scenes have also received attention from Mark Morford in The Poet Lucan (Oxford, 1967) and from Oskar Schrempp in Prophezeiung und Rückschau in Lucans "Bellum Civile" (Winterthur, 1964). The most recent discussion of the subject is Frederick M. Ahl's "Appius Claudius and Sextus Pompey in Lucan," C\&M 30 (1969): 331-46.

2. The story of Appius' visit to Delphi was a stock exemplum in Latin literature. It occurs in Orosius (6. 15. 11), who tells it briefly, and in a longer version in Valerius Maximus (1. 8. 10).

3. Dick, "Oracle," p. 461, following the research of Constans, has pointed out the appropriateness of Appius as a consulter of Delphi because of his interest in divination and magic. Syme, The Roman Revolution" (Oxford, 1952), p. 45, refers to "the enigmatic Appius Claudius Pulcher, proud, corrupt. and superstitious." 
when Appius has been frustrated in his quest, Lucan will call him demens (288). So besides being a coward, this consulter is a fool. ${ }^{4}$

The oracle Appius has chosen is Delphi, which must be understood to be the representative of the superi dei. Lucan's description of the shrine is confusing in the extreme. Immediately after announcing the visitation, he launches into a solemn epic passage on the mythological and religious significance of this prophetic seat (71-85). H. P. Syndikus thinks that the purpose of the passage is to impress upon the reader the importance and dignity of the oracle. ${ }^{5}$ The feeling of solemnity, however, is shattered in the next line when the poet turns philosopher and speculates on the identity of the deity resident at Delphi. At line 85 we hear that the prophet is Apollo. (The use of the proper name as the last word of the line is emphatic.) But beginning at line 86 , in a jarring shift from epic description to rationalistic speculation, comes a series of questions on the god's identity: "quis latet hic superum? quod numen ... ? quis terram caeli patitur deus . . . ?" Unclear also is the deity's relation to fate, and the poet asks whether he determines destiny or simply prophesies it (92-93). Lucan speculates that perhaps a part of the divine element, which he now calls Jove, may be embedded here, occasionally to enter the bosom of the priestess (93-101). Earlier, in a more poetic moment, Lucan had spoken of mephitic exhalation as the source of oracular prophecy: "ut vidit Paean vastos telluris hiatus / divinam spirare fidem ventosque loquaces / exhalare solum" (82-84). So before the actual visitation we hear a number of conflicting theories and questions about the god. It may be Apollo, it may be the all-pervasive deity going under the name of Jove, or it may be some anonymous god whose name and nature are unknowable. ${ }^{6}$ And as for prophecy, the possibility seems slim, since Delphi is described as closed and silent $(69,120-21)$. We approach the oracle with a degree of uncertainty and wariness.

Our suspicions, already aroused by the poet's speculative description, are further compounded by the actions of the priestess Phemonoe. Afraid to undergo possession by the god, she refuses to cooperate with Appius or with the priest, who has to push her bodily into the sanctuary. Still she resists and attempts to persuade the consulter that the god is silent. This anomalous situation becomes a ludicrous one when Phemonoe simulates ecstatic communion with Apollo (and a bad job she does of it) in order to deceive Appius, who finally puts a stop to the nonsense by threatening her with death. There follows a detailed description of her frenzy, induced, we are told, by Apollo. The scene climaxes with the prophecy (194-96):

\footnotetext{
effugis, ingentes, tanti discriminis expers, bellorum, Romane, minas, solusque quietem Euboici vasta lateris convalle tenebis.
}

4. I cannot agree with Ahl that Appius' motive in visiting the oracle is simply academic curiosity ("Appius Claudius and Sextus Pompey in Lucan," p. 337).

5. Lucans Gedicht vom Bürgerkrieg: Untersuchungen zur epischen Technik und zu den Grundlagen des Werkes (Munich, 1958), p. 73.

6. For a discussion of the various theories on Delphi current in Lucan's time see Dick, "Oracle," pp. 460-64. The author concludes that Lucan at times stoicizes the explanation of the oracle though without committing himself to any single theory. 
One might well ask, three lines? Is that all? After the grandiose introduction and the weighty philosophical speculation, after the trouble of forcing a prophecy out of the priestess, all we learn is that Appius will escape the threat of war and find peace somewhere in Euboea.

This anticlimax prompts the disappointed poet to interject his own persona into the situation. Accusing the gods of plotting evils too terrible to disclose, he, as omniscient narrator, reveals what Apollo conceals: the Roman empire will collapse (200-201); the leading men in the war will be slaughtered (201); many nations will suffer bloodshed and destruction (202); Pompey and Caesar will be murdered (205-8). Nor does Lucan forget Appius, whom he tells (231-36):

litoris Euboici memorando condite busto, qua maris angustat fauces saxosa Carystos et, tumidis infesta colit quae numina, Rhamnus, artatus rapido fervet qua gurgite pontus Euripusque trahit, cursum mutantibus undis, Chalcidicas puppes ad iniquam classibus Aulin.

Lucan here elucidates in straightforward fashion what the priestess only hinted at. Yes, Appius will find peace and safety, but they will be the peace and safety which come only with the end of life. ${ }^{7}$

The whole point of Delphi's riddling message to Appius-and this is significant-is death. And this is the import also of Lucan's own predictiondeath for Appius, for Rome, and for a large portion of mankind as well. B. F. Dick has made the illuminating observation that in the Pharsalia all predictions of the future have one point in common. In his words:

Unlike the prophecies in the Aeneid, those in the De bello civili are all concerned with death and underscore the poet's thesis that knowledge of the future annihilates hope. Prodigies burden mankind, magically induced prophecies portend death, and dreams presage annihilation for the dreamer. The poet's narrative predictions are concerned only with death and continued warfare. In Lucan's hands, prophecy becomes an epic device used for the ulterior motive of showing its futility. ${ }^{8}$

The truth of this statement is borne out by the second half of Book 1, in which Arruns foresees unspeakable disaster (631-37), Figulus speculates on celestial and terrestrial upheaval (642-72), and the raving matron predicts the battles of Pharsalus, Thapsus, Munda, and Philippi, as well as the deaths of Pompey, Cato, and Caesar (678-95). The only certitude about the future is death.

One thesis of the Pharsalia is that doom is universal and inevitable. The conflict will leave Rome destroyed, political freedom extinguished, and the architects of the war assassinated. Only the preservation of personal liberty has a chance of success; but, as the case of Cato shows, the paradoxical price of even that success is the sacrifice of life itself. In the end, death and failure await victor and vanquished alike. But what about a man like Appius?

7. Appius did not live to see the battle of Pharsalus, having died of illness in Euboea. See Val. Max. 1. 8. 10.

8. "Prophecy," p. 49. 
As far as the war goes, he is insignificant, with no great part to play. His walk-on role confined to this one scene is indicative of his unimportance. We remember that in her vision Phemonoe had difficulty finding him: "inter fata diu quaerens tam magna latentem" (189). Yet, trivial as he is, he shares the same destiny as those who overshadow him with their greatness. Pompey and Caesar will wage the war and then perish as victims of its violence. Appius will remain uninvolved and die naturally and peacefully in Euboea. Although the storm of war will leave him untouched, still he will not escape physical destruction. Be men great or small, participants in the conflict or spectators, annihilation awaits one and all. And it is the function of the Delphi episode to demonstrate this truth.

Since the future holds the same destiny for all mankind, the desire for foreknowledge is misguided and foolish. Only those too blind to see reality, or too cowardly to face it, need consult oracles. Appius is such a man and deserves the poet's scorn. One recalls the words of Seneca: "quam ideo timere dementis est quia certa expectantur, dubia metuuntur. mors necessitatem habet aequam et invictam." 9

Lucan's opinion on the worthlessness of foreknowledge is implicit throughout this episode, and elsewhere it is voiced in no uncertain terms. At the opening of Book 2, for example, immediately after a lengthy sequence of ominous prodigies and prophecies, he asks of heaven $(4-6,14-15)$ :

cur hanc tibi, rector Olympi,

sollicitis visum mortalibus addere curam, noscant venturas ut dira per omina clades?

sit subitum quodcumque paras; sit caeca futuri mens hominum fati; liceat sperare timenti.

Better to live in ignorance of the future and still have some hope. ${ }^{10}$

It is interesting to observe that while some characters like Appius are too foolish to realize what lies ahead, a great many others instinctively know the future without the aid of oracles or prophecies. As he takes leave of Italy, Pompey knows in his heart that he will never see his country again (3. 5-6). His wife Cornelia is aware of the disaster at Pharsalus even before she meets her spouse (8. 41-49). As the Pompeian party approaches Egypt, the companions of Magnus all have premonitions of what will happen: "non ulli comitum sceleris praesagia derant" (8. 571). The character with the clearest vision of the future is Cato, who long before the battle of Pharsalus knows that the republic will die, that tyranny is inevitable, and that neither he nor liberty will survive one another (2. 297-318).

It should be noted also that Lucan depends on the reader's own foreknowledge in order to create a feeling of impending doom. For like the Aeneid, the Pharsalia contains predictions of actual historical events. But

9. Ep. 30. 10-11.

10. This is a stoic notion. Cf. Sen. Ep. 24. 1: "quid enim necesse est mala accersere, satis cito patienda cum venerint, praesumere, ac praesens tempus futuri metu perdere? est sine dubio stultum, quia quandoque sis futurus miser, esse iam miserum." 
while Vergil's epic prophesies the birth of Rome and Golden Age of Augustus, Lucan's foresees only its death and enslavement under the Caesars. By taking past and present events and predicting them as if they lay in the future, Vergil conveys a sense of grand destiny unfolding in the history of Rome. Lucan does something very similar; only, by predicting the downfall of the republic and the emergence of a tyranny, he achieves the opposite effect. In the Pharsalia almost every person and every event is overshadowed by disaster or death. Syndikus makes the observation that Lucan, in structuring his scenes, never builds to a climax created by a sudden reversal of fortune. He adduces the Curio episode, which had a cloud of gloom over it from the beginning, long before the disastrous ending. ${ }^{11}$ Even the narration of the Pompeian victory at Dyrrhachium is darkened by the shadow of Pharsalus. ${ }^{12}$

If foreknowledge is superfluous, then oracles are useless. And Delphi is worse than useless because it veils even the simple certitude of death in obscurity in order to frustrate foolish mortals like Appius. It is clear that Lucan has intentionally portrayed the oracle as ambiguous and unworthy of belief. The inconsistent mixture of mythology and rationalism purposely contributes to a feeling of confusion and suspicion. All this is meant to reflect badly upon the superi dei, who have determined to destroy mankind and subject the world to threatening portents Rightly does Lucan call them superi minaces (1.524).

Although the episode of Appius at Delphi may be actionless and bear little relation to the "plot," it is nonetheless a rich and carefully constructed scene. In it converge a number of important themes: the futility of foreknowledge, the inefficacy of divination, the malevolence of the superi, and the certitude of death. It might also be added that Lucan has appropriately sketched Appius as a fitting consulter of Apollo's riddling oracle. Yet strangely enough, scholars have not appreciated the episode in its own right and have regarded it as mere foreshadowing at best. W. E. Heitland dismisses it as "padding"-presumably because it centers on an insignificant character who appears only once and because it does little to advance the action toward Pharsalus. ${ }^{13}$ Syndikus calls the characterization of Appius unimportant. ${ }^{14} \mathrm{O}$. Schrempp thinks that everything in the scene before Lucan's own reflection at line 198 is of little relation to the main theme, ${ }^{15}$ while M. P. O. Morford considers the whole story a trite excursus. ${ }^{16}$ Failure to appreciate this episode for its own sake results either from overemphasizing the "plot" of the civil war, or from exaggerating the importance of the battle of Pharsalus. The fact is, many scenes only marginally connected to the central action are carriers of important themes.

11. Lucans Gedicht, p. 47.

12. Ibid., pp. 48-49.

13. W. E. Heitland, in his introduction to C. E. Haskins (ed.), M. Annaei Lucani "Pharsalia" (London, 1887), p. xxxiii.

14. Lucans Gedicht, p. 111.

15. Prophezeiung und Rückschau, p. 23.

16. The Poet Lucan, p. 65. 
The second character to visit an oracle is another republican, Pompey's son Sextus, who chooses to consult the Thessalian witch Erichtho. Again, it is important to consider Lucan's characterization of the consulter, the portrayal of the oracle, and, in addition, references to Delphi. We may also look for elaboration of themes touched upon in the earlier episode.

As might be expected, Lucan's portrait of Sextus is far from flattering. $\mathrm{He}$ is introduced with these words $(6.417-22)$ :

degeneres trepidant animi peioraque versant;
ad dubios pauci praesumpto robore casus
spemque metumque ferunt. turbae sed mixtus inerti
Sextus erat, Magno proles indigna parente,
cui mox Scyllaeis exul grassatus in undis
polluit aequoreos Siculus pirata triumphos.

Again, the motive for seeking foreknowledge is fear. Like Appius, this consulter is a coward. Still worse, he is an evil man, the unworthy son of a great father, who will one day become a pirate. It is no surprise that he fears the future and seeks information from the occult: "qui stimulante metu fati praenoscere cursus, / inpatiensque morae venturisque omnibus aeger" (42324). But unlike Appius, Sextus disdains the oracles of the superi. His reason is significant (430-34):

ille supernis

detestanda deis saevorum arcana magorum noverat et tristis sacris feralibus aras, umbrarum Ditisque fidem, miseroque liquebat scire parum superos.

He refuses to consult Delos, Delphi, and Dodona, and rejects extispicy, haruspicy, and astrology on the grounds that the superi know nothing. And from what we saw of Apollo's performance at Delphi, we must admit that he is correct. He believes that superior knowledge lies with Thessalian witches and with Erichtho most of all. Sextus' preference for this "oracle" over a more conventional one signals a contest between Apollo and the sorceress.

Thessalian necromancy is worlds removed from the prophecy of Pythian Delphi. But is it more efficacious? Does this witch have any more power or certitude than the oracle of Delphi? And if she does, will she reveal it more clearly? The answer to all these questions is an unqualified yes.

Lucan's preliminary description of Erichtho's abode and its environs stands in stark contrast to his introduction to Delphi. Nowhere is there intentional inconsistency or rationalistic speculation to cast doubt on the power of black magic. The description begins with Thessaly itself, source and site of many evils (333-412), then moves on to an account of the magic practiced there (434-506), and climaxes in the portrait of Erichtho, the necrophagous witch, whose doings are recounted with no effort to spare the 
squeamish (507-569). ${ }^{17}$ Every detail in the introduction to the prophecy is designed to create a sense of the overwhelming potency of necromancy.

Two points in these passages are striking: first, the great emphasis on death; second, the total superiority of the inferi dei over the superi. Everything about Erichtho-her spells, rituals, and rites-is directed toward inflicting death. Not only does she lord it over humanity, but she even subjects heaven to her whims (443-47). Human emotions (454-55), the natural laws of the universe (462 ff.), all yield to her will. Even Jupiter and Apollo are helpless in the face of her art (462-67). This unnatural inversion in the order of things prompts Lucan to exclaim (492-99):

quis labor hic superis cantus herbasque sequendi
spernendique timor? cuius commercia pacti
obstrictos habuere deos? parere necesse est,
an iuvat? ignota tantum pietate merentur,
an tacitis valuere minis? hoc iuris in omnis
est illis superos, an habent haec carmina certum
imperiosa deum, qui mundum cogere quidquid
cogitur ipse potest?

He has questions to ask about this oracle as he did about Delphi. But these questions cast no doubt upon the efficacy of witchcraft. Rather, they confirm the feeling that Erichtho's magic is infinitely more potent than anything the traditional oracles could offer. We are invited to conclude that the realm of hell has usurped the prerogatives of heaven and assumed control of the universe. It is interesting to note that this inversion occurred as early as Book 1, when Arruns, after performing a rite of extispicy, cried out (631-34):

vix fas, superi, quaecumque movetis, prodere me populis; nec enim tibi, summe, litavi, Iuppiter, hoc sacrum, caesique in pectora tauri inferni venere dei.

Arruns' suspicion that the inferi dei hold sway over the superi is confirmed beyond all doubt by Erichtho.

Sextus' purpose in searching out the witch is to learn the future. Specifically, he wants to know who will die: "quos petat e nobis, Mortem mihi coge fateri" (601). Too foolish to realize that this question needs no answering, he comes to the very realm of death to have it spelled out. And in contrast to Appius he is not frustrated. For the sorceress, in an amazing display of power over life and death, raises up a cadaver and bids it prophesy. Notice that there is no equivocation, no unwillingness as on the part of Phemonoe. This soothsayer has sure and certain knowledge of the future and will gladly impart it. In her command to the corpse she casts aspersions on the oracles

17. For a discussion of Roman magical practices as well as of the literary antecedents of this episode, see Morford, The Poet Lucan, pp. 67-70. 
of the superi, and her reference to the tripod is a direct attack on Delphian Apollo (770-73):

tripodas vatesque deorum

sors obscura decet: certus discedat, ab umbris quisquis vera petit duraeque oracula mortis fortis adit.

The upper gods may mock their consulters with riddles, but the oracles of death will dispense truth without hesitation to those with the courage to approach them. Accordingly, Erichtho orders the resurrected body to give all the particulars: "da nomina rebus, / da loca: da vocem qua mecum fata loquantur" (773-74).

Unlike Phemonoe, who temporized, dissembled, and then delivered only three enigmatic lines, the corpse complies immediately and gives the clearest, most detailed prophecy of the Pharsalia. In no uncertain terms, it reveals the disturbance of the civil war, a catalog of doomed leaders, and the fate of the house of Pompey. The prophecy alludes to the death of Scipio (78889), the murder of Caesar (791-92), and the suicide of Cato (789-90). We learn that Elysium is reserving a place for Pompey (803-5). The entire message given by the cadaver can be summed up in one word, death (806811):

veniet quae misceat omnis

hora duces. properate mori, magnoque superbi

quamvis e parvis animo descendite bustis

et Romanorum manes calcate deorum.

quem tumulum Nili, quem Thybridis adluat unda

quaeritur, et ducibus tantum de funere pugna est.

Both Caesar and Pompey will die as a result of the war; the only question to be determined by the conflict is who will be buried in Egypt and who in Rome. Sextus is not told his fate specifically, ${ }^{18}$ but hears allusions to the deaths of himself, his brother, and their father: "Europam, miseri, Libyamque Asiamque timete" (817). These are the three lands over which Pompey had triumphed. More significantly for this scene, these are also the places where the members of Pompey's family met their deaths: Gnaeus in Spain after Munda, Magnus in Egypt after Pharsalus, and Sextus in Asia after Naulochus.

The cadaver's prophecy rings with the names of the illustrious figures who fought the war and then met the same end. In this way, the episode develops the theme of universal doom introduced earlier at Delphi. Phemonoe's prophecy showed that death awaits an insignificant, uninvolved individual like Appius. Here the oracle of Erichtho teaches that the high and the mighty may expect the same fate. Caesar's power, Pompey's luck, and

18. The cadaver tells Sextus not to inquire into his own future now, but says that his father will appear to him later and prophesy. It is noteworthy that it says that Pompey will not be able to give him any specific information about what to do and where to go. Although this part of the poem was never written, we can safely surmise, judging from all the other prophecies, that Pompey's message would have concerned death. 
Cato's virtue cannot save them from the sentence which makes all men equal. Both Appius and Sextus have received prophecies appropriate to their personalities and stations in life.

In one respect the two oracles complement each other; in another they contrast, that is, in their certitude. As we saw, and as Erichtho claimed, the oracles of the upper gods deal only in enigmas. Apollo's message is death, but he conceals that truth in obscurity. At the oracula mortis the message is the same, but with the difference that it is clear and unequivocal. The point is thus unmistakable: certitude lies not with the upper gods or in the land of the living, but with the infernal deities, that is, in death!19

The third and final oracle of the Pharsalia is that of Jupiter Hammon, which Cato goes out of his way to visit in the course of the desert march (9. 511-86). ${ }^{20} \mathrm{It}$ contains, as Morford says, "Lucan's mature views on divination." ${ }^{21}$ As in the two previous scenes, we must consider the character of the man and the nature of the prophetic seat.

The subject of Cato's personality need not detain us long. Suffice it to say that he is a good and holy man, the stoic sapiens, the virtutum viva imago. ${ }^{22}$ The situation is unique because for the first time a man who encounters an oracle is neither fool nor coward. And it should be remembered that from the moment of his first appearance in Book 2 Cato displays a heroic attitude toward death, entertaining no delusion either about his own fate or about the fate of Rome.

As for Jupiter Hammon, Lucan depicts him favorably. This is unusual for a poet who shows himself elsewhere either as rationalist or contemptor divum. He refers sympathetically to the oracle's great reputation and adduces a number of details attesting to the real presence and integrity of the god. Hammon's poverty contrasts with the riches of Roman temples (51921); the trees and oasis testify that the god does indeed reside here (522-27); and finally the wealth of astronomical detail lends weight and importance to the temple's celebrated oracular powers (528-44). In contrast to Delphi, Hammon arouses no suspicion or rationalistic questioning; and in contrast to Erichtho, there is nothing distasteful or repellent in the appearance of the god. Here at last is an oracle commanding the respectability of Delphi as well as the efficacy and credibility of Erichtho. Worthy also, as Labienus insists, is the man standing at the door of the temple.

Cato, however, is no Appius and certainly no Sextus. Requested to inquire into the death of Caesar and the fate of the republic, he refuses and

19. The importance of the Erichtho episode has also been underestimated. Syndikus appreciates it only for its foreshadowing, and thinks the characterization of the consulter irrelevant (Lucans Gedicht, p. 36): "Wie hier Appius, ist im 6. Buch Sextus Pompeius nur äusserer Anlass zu einer Prophezeiung, die auf Grösseres zielt." Morford, The Poet Lucan, p. 66, sees the episode "primarily as a prelude to the climax at Pharsalia."

20. The episode is modeled on Alexander's visit to the same oracle. See Arr. 3. 3-4; Curt. 4. 7. 2232; and Plut. Alex. 37. For a discussion of Lucan's use of the Alexander tradition in this scene and elsewhere, see Werner Rutz, "Lucan und die Rhetorik," in Lucain, ed. Marcel Durry, Fondation Hardt, Entretiens 15 (Geneva, 1970), pp. 235-57.

21. The Poet Lucan, p. 73

22. Sen. Tranq. 16. 1. 
delivers a pronouncement worthy of the oracle itself: "dignas adytis e pectore voces" $(565) .{ }^{23} \mathrm{He}$ has nothing to ask, and in a series of rhetorical questions he makes it clear that he already possesses any knowledge the god might have to give. He would prefer to die a free man rather than submit to tyranny. The length of one's life is immaterial, virtue is impervious to the outrages of fortune, and honor is worth following for its own sake (566-71). These truths being planted in his heart, he has no use for divination (576-80):

sterilesne elegit harenas

ut caneret paucis, mersitque hoc pulvere verum, estque dei sedes nisi terra et pontus et aer et caelum et virtus? superos quid quaerimus ultra?

Iuppiter est quodcumque vides, quodcumque moveris.

Only cowards and fools require from oracles the truth they cannot find in themselves: "sortilegis egeant dubii semperque futuris / casibus ancipites" $(581-82)$. Death is the only certitude and oracles can give no other (582-84):

me non oracula certum

sed mors certa facit. pavido fortique cadendum est:

hoc satis est dixisse Iovem. ${ }^{24}$

Fools may seek the enigmatic trivialities dispensed by Delphi, and cowards may seek the loathsome certitude revealed by Erichtho. But the wise man, living in the shadow of sure and certain death, needs neither heaven nor hell.

\section{Loyola University of Chicago}

23. Cf. Seneca Rhetor Controv. 1. 9: "erratis, optimi iuvenes, nisi illam vocem non M. Catonis sed oraculi creditis. quid enim est oraculum? nempe voluntas divina hominis ore enuntiata; et quem tandem antistitem sanctiorem sibi invenire divinitas potuit quam M. Catonem per quem humano generi non praeciperet sed convicium faceret?"

24. Cf. Sen. Ep. 71. 15: "itaque ut M. Cato, cum aevum animo percucurrerit, dicet, 'omne humanum genus, quodque est quodque erit, morte damnatum est.' "' 